\title{
Identifikasi Suara Pada Sistem Presensi Karyawan Dengan Metode Ekstraksi Ciri MFCC
}

\author{
YUWONO FITRI WIDODO' ${ }^{1}$, SUNARDI ${ }^{2}$, ADBUL FADLIL ${ }^{3}$
}

${ }^{1}$ Magister Teknik Informatika (Universitas Ahmad Dahlan, Yogyakarta)

2Program Studi Teknik Elektro (Universitas Ahmad Dahlan, Yogyakarta)

${ }^{3}$ Program Studi Teknik Informatika (Universitas Ahmad Dahlan, Yogyakarta)

Email : yuwono1708048020@webmail.uad.ac.id

\begin{abstract}
ABSTRAK
Biometrik adalah ilmu yang mempelajari pola ciri-ciri untuk mengenali atau mengidentifikasi manusia berdasarkan satu atau lebih dari bagian tubuh manusia, baik ciri-ciri kimia, fisik, maupun tingkah laku, seperti wajah, sidik jari, suara, geometri tangan, ataupun iris mata. Saat ini sudah berkembang teknologi menggunakan suara untuk dijadikan sebuah aplikasi yang memudahkan manusia. Proses identifikasi suara sangat diperlukan untuk mengetahui keakuratan suara berdasarkan ciri yang dimiliki, karena beberapa manusia memiliki kemiripan dalam berucap. Pada penelitian ini bertujuan untuk mengetahui pola suara berdasarkan ucapan. Metode yang digunakan untuk identifikasi suara menggunakan metode ekstraksi firur Mel-Frequency Cepstral Coefficients (MFCC), merupakan metode ekstraksi fitur yang mendekati sistem pendengaran manusia dan mampu untuk mengenali pola ucapan.
\end{abstract}

Kata kunci: biometrik, identifikasi, mfcc, suara.

\begin{abstract}
Biometrics is the study of patterns of traits to recognize or identify humans based on one or more parts of the human body, both chemical, physical, and behavioral characteristics, such as faces, fingerprints, sounds, hand geometries, or iris. Nowadays technology has developed using sound to be used as an application that makes it easy for humans. The process of voice identification is very necessary to determine the accuracy of sound based on the characteristics possessed, because some humans have similarities in speech. In this study aims to find out sound patterns based on speech. The method used for voice identification using the extraction method of the Mel-Frequency Cepstral Coefficients (MFCC), MFCC is a feature extraction method that approaches the human hearing system and is able to recognize speech patterns.
\end{abstract}

Keywords: biometric, identification, mfcc, voice. 



\section{PENDAHULUAN}

Dewasa ini perkembangan teknologi begitu pesat diberbagai bidang. Salah satu bidang dari kemajuan teknologi ini adalah kecerdasan buatan. Dalam kegiatan sehari-hari dapat dijumpai alat-alat berteknologi dari perkembangan ilmu kecerdasan buatan yang digunakan untuk membantu pekerjaan manusia. Salah satu perkembangan kecerdasan buatan adalah biometrik pengenalan pola. Biometrik adalah ilmu yang mempelajari pola ciri-ciri untuk mengenali atau mengidentifikasi manusia berdasarkan satu atau lebih dari bagian tubuh manusia, baik ciri-ciri kimia, fisik, maupun tingkah laku, seperti wajah, sidik jari, suara, geometri tangan, ataupun iris mata.

Menurut Kamus Besar Bahasa Indonesia Suara adalah bunyi yang dikeluarkan dari mulut manusia (seperti pada waktu bercakap-cakap, menyanyi, tertawa, menangis, bunyi binatang, alat perkakas dan sebagainya). Menurut Fadlisyah dkk (2013) suara merupakan suatu bentuk dari sebuah komunikasi. Manusia dapat menghasilkan suara untuk berkomunikasi dengan menggunakan pita suara yang terdapat dirongga mulut dan suara yang dihasilkan mempunyai frekuensi yang berbeda-beda. Frekuensi yang dapat didengar oleh telinga manusia antara $20 \mathrm{~Hz}$ sampai dengan $20.000 \mathrm{~Hz}$.

Saat ini sudah berkembang teknologi menggunakan suara untuk dijadikan sebuah aplikasi yang memudahkan manusia. Salah satunya adalah untuk presensi kehadiran karyawan menggunakan suara. Kelebihan dari teknologi ini adalah memudahkan dalam proses absensi. Selain keamanan sistem tinggi hal yang menjadi kekurangannya adalah apabila ada kemiripan suara atau perubahan suara dari pemilik maka sistem akan menolaknya. Proses identifikasi suara sangat diperlukan untuk mengetahui keakuratan suara berdasarkan ciri yang dimiliki, karena beberapa manusia memiliki kemiripan dalam berucap. Permasalahan ini menjadi dasar penulis untuk melakukan penelitian bagaimana mengidentifikasi suara ucapan yang identik berdasarkan ciri-ciri yang dimiliki. Adapun dalam ekstraksi ciri digunakan metode Me/Frequency Ceptrum Cooeficient (MFCC). Metode ini dilakukan dengan memasukkan data suara pengucap ke software Matlab.

\section{METODE PENELITIAN}

Proses dalam penelitian ini adalah melakukan identifikasi suara untuk menentukan suara yang identik atau tidak identik sesuai dengan suara seseorang. Teknik dan tahapan yang digunakan terdiri dari beberapa langkah seperti berikut:

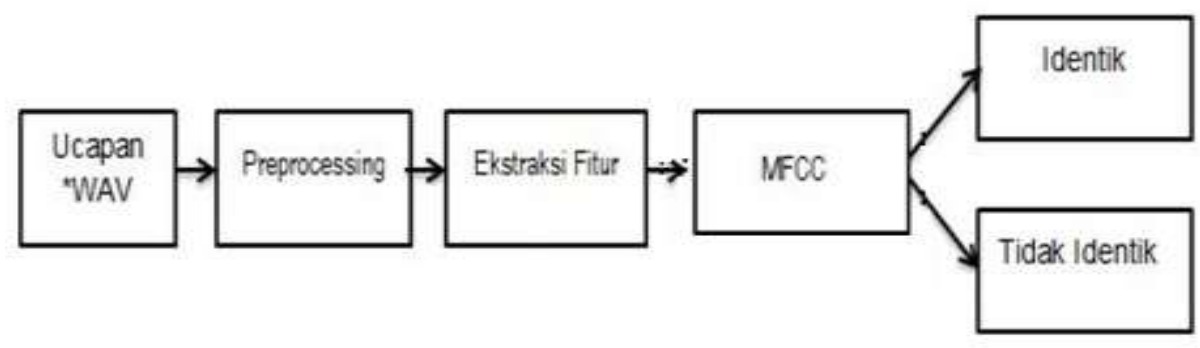

Gambar 1. Alur poses Identifikasi 


\subsection{Data yang digunakan dalam penelitian ini menggunakan data suara karyawan}

Basis data ini berisi rekaman data audio yang terdiri dari lima aktor, yaitu tiga pria dan dua wanita. Basis data ini berisi sekitar 250 sampel ucapan dari 5 peserta, sampel yang diambil adalah yang memiliki tingkat pengenalan manusia yang lebih baik dari $80 \%$ dan nilai kealamian lebih dari $60 \%$.

\subsection{Sampel Ucapan}

Sampel pada penelitian ini sebanyak 50 data, dan akan dibagi menjadi dua yaitu untuk data latih dan data uji. Kalimat yang diucapkan adalah kata "Login" dengan suara yang diambil dari 5 aktor. Pada tahap ini, sampel ucapan dalam bentuk file *.wav dirubah menjadi sinyal ucapan dengan menggunakan aplikasi MATLAB R2013a. Sinyal ucapan ini akan menjadi deretan nilai dalam satuan matriks.

\subsection{Pre-processing}

Tahapan ini melakukan pre-processing pada rekaman yaitu dengan melakukan pemotongan rekaman suara sebagai sampling pada saat ektraksi fitur. Tujuan dari sampling ini adalah agar pola dapat terlihat berbeda untuk masing-masing ucapan tertentu.

\subsection{Sinyal Ucapan}

Setelah tahapan pemotongan suara sebagai sampling tahapan selanjutnya adalah sinyal ucapan. Tahapan ini mengubah sampel ucapan bentuk file .wav menjadi sinyal ucapan yang dapat dibaca oleh komputer.

\subsection{Ekstraksi Fitur}

Ekstraksi ciri yang digunakan pada penelitian ini adalah menggunakan metode MFCC yang dimana metode ini adalah metode ekstraksi ciri yang mendekati sistem pendengaran manusia. MFCC sering digunakan untuk pemrosesan suara, karena dapat merepresentasikan sinyal dengan baik. Proses ekstraksi fiturnya adalah sebagai berikut:

\subsubsection{Pre-emphasis}

Proses pertama yaitu pre-emphasi, tujuannya adalah untuk filtering sinyal ucapan dan mengurangi nilai frekuensi sinyal suara masukkan sehingga hanya sinyal yang memiliki frekuensi tinggi yang dapat melewati proses filter. Selain itu juga dapat mengurangi noisenoise pada suara masukkan, sehingga hanya sinyal ucapan saja yang dapat ditangkap sistem. Persamaannya dapat dilihat pada rumus (1).

$$
\rho(n)=s(n)-x s(n-1)
$$

dimana $\mathrm{x}$ adalah konstanta filter pre-emphasis, biasanya bernilai antara $0.9<\mathrm{x}<1.0$

\subsubsection{Framing}

Pada proses ini input suara dipotong menjadi beberapa frame dengan durasi yang lebih pendek sebanyak matriks (M) yang disimpan di matriks Y dengan ukuran MxW. Sinyal suara dilakukan segmentasi menjadi beberapa frame dengan cara tumpang tindih (overlap) agar tidak ada sinyal yang hilang. Proses ini terus berlanjut sampai seluruh sinyal masuk ke dalam satu atau lebih frame. 


\subsubsection{Windowing}

Proses windowing dilakukan dengan tujuan untuk memperoleh sampel sinyal yang tepat dalam waktu interval yang sangat singkat. Proses ini menghasilkan window $X(\mathrm{t})$ dimana $\mathrm{t}=1,2,3, \ldots . \mathrm{T}$ yang disebut frame. Pada kasus ini akan menggunakan persamaan hamming window dengan rumus (2).

$$
w((\mathrm{n})=0,54+0,46 \cos 2 \pi \mathrm{nN}-1,0 \leq \mathrm{n} \leq \mathrm{N}-1)
$$

dimana $\mathrm{n}$ adalah jumlah sampel dan $\mathrm{N}$ adalah jumlah frame 2.5.4. Fast Fourier Transform (FFT) FFT adalah salah satu metode untuk mengkonversikan dari sinyal suara menjadi sinyal

frekuensi. Proses ini akan dilakukan terhadap semua frame dari sinyal yang sudah di windowing. FFT merupakan algoritma cepat untuk menerapkan Discrete Fourier Transform (DCT) yang beroperasi pada sinyal diskrit yang terdiri dari $\mathrm{N}$ sampel, persamaannya dapat dilihat pada rumus (3).

$$
f(n)=\Sigma w k N-1 K=0 \mathrm{e}-2 \pi \mathrm{jkn} / \mathrm{N}, 0 \leq \mathrm{n} \leq \mathrm{N}-1
$$

dimana w adalah windowing.

\subsubsection{Mel Filterbank}

Mel-Filterbank merupakan triangular dari filterbank, yang membedakan adalah range frekuensi linier dari hasil FFT yang kemudian dikonversi ke skala Mel-Frequency untuk mendapatkan batas-batas filterbank. Persamaan Mel Filterbank ada pada rumus (4) .

$$
B(f))=1125 \times \ln (1+\mathrm{f} 700)
$$

Proses Mel-Filterbank yang perlu dilakukan adalah menentukan batas atas dan bawah dari filter. Kemudian bagi range batas atas dan bawah sesuai dengan jumlah filter yang dibuat dan dapat diketahui batas atas dan bawah untuk setiap filterbank dalam skala mel. Kedua batas tersebut dikonversi kembali ke skala frekuensi linier.

\subsubsection{Discrete Consine Trasform}

Proses terakhir adalah pengkonversian domain frekuensi ke domain waktu dengan menggunakan Discrete Cosine Transform (DCT). Hasil log dari perkalian domain waktu menggunnakan DCT menghasilkan mel-frequency cepstrum coefficient (MFCC). Berikut adalah persamaan yang digunakan (5):

$$
C j=\Sigma \operatorname{Xicos}(\mathrm{j}(\mathrm{i}-1) / 2 \pi \mathrm{M})
$$

dimana $\mathrm{j}=1,2,3 \ldots \mathrm{K}$ adalah koefesien, dan $\mathrm{M}$ adalah jumlah filter. 3. 


\section{HASIL DAN PEMBAHASAN}

Penelitian ini menggunakan beberapa sampel suara dari karyawan dengan mengambil sampel kalimat "Login" Rekaman suara tersebut kemudian di pre-processing. Pada penelitian ini digunakan lima sampel suara untuk masing-masing percobaan. Sampel suara tersebut juga diucapkan oleh aktor yang berbeda. Sampel-sampel suara tersebut di cari polanya dengan menggunakan ektraksi fitur MFCC dengan beberapa parameter yaitu Tw = 25; sebagai durasi masing-masing frame, $\mathrm{Ts}=10$; sebagai pembentukan frame, alpha $=0.97$; sebagai nilai koefesien preemphasis, $M=20$; sebagai nilai filterbank pada setiap channels, $C=12$; nilai cepstral coefficients, dari parameter tersebut dihasilkan fitur MFCC. Hasil dari ektraksi suara menggunakan MFCC dapat dilihat dilihat pada Gambar.2. suara yang sudah diekstraksi kemudian dianalisis dengan normalisasi sehingga terlihat pola suara seperti pada gambar 3. Proses perhitungan normalisasi dari ekstraksi ciri dilakukan untuk menyamakan nilai pola yang dapat dilihat pada tabel 1 . Setiap gambar menampilkan sampel untuk setiap ciri suara yang telah dianalisis.
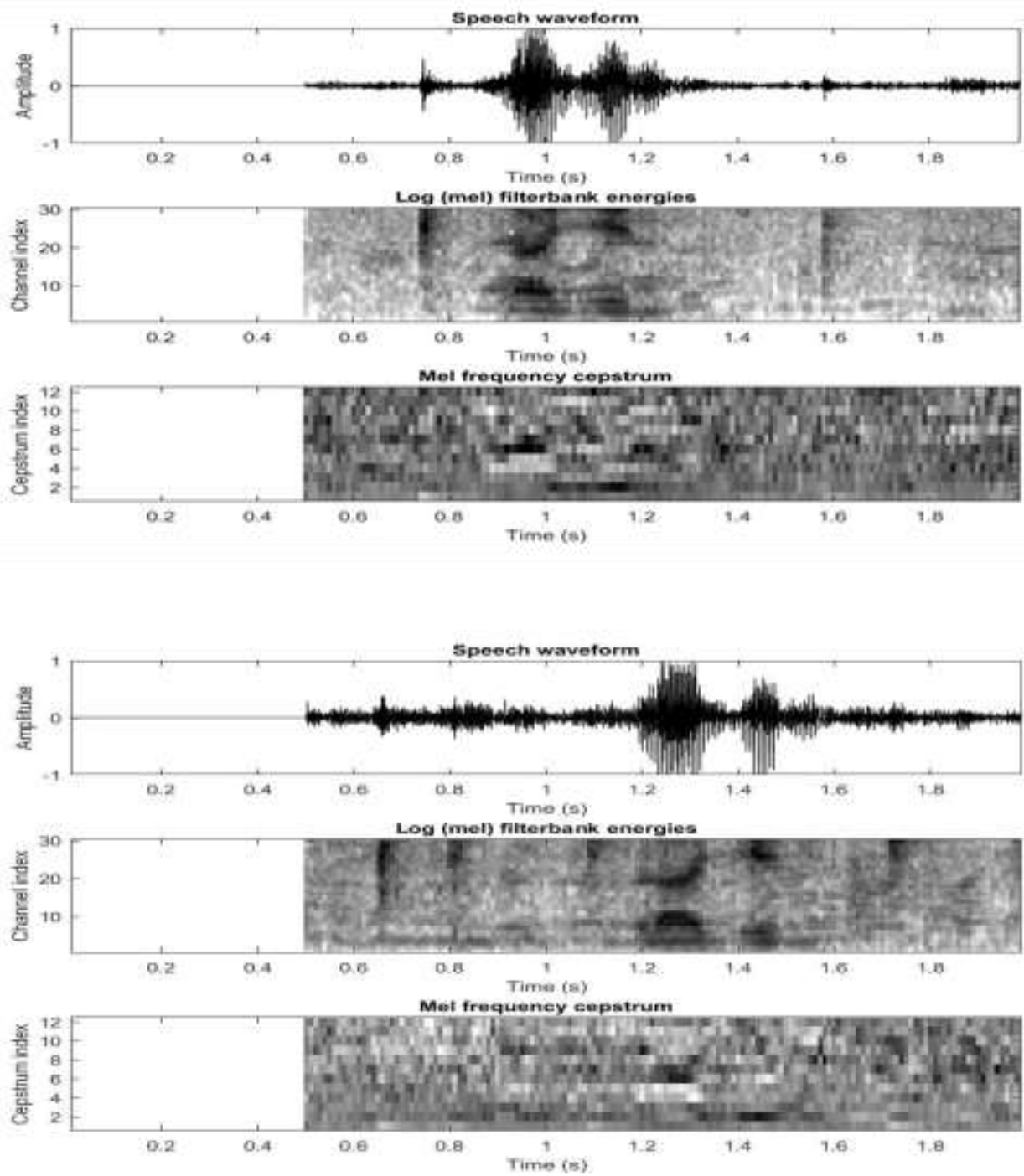

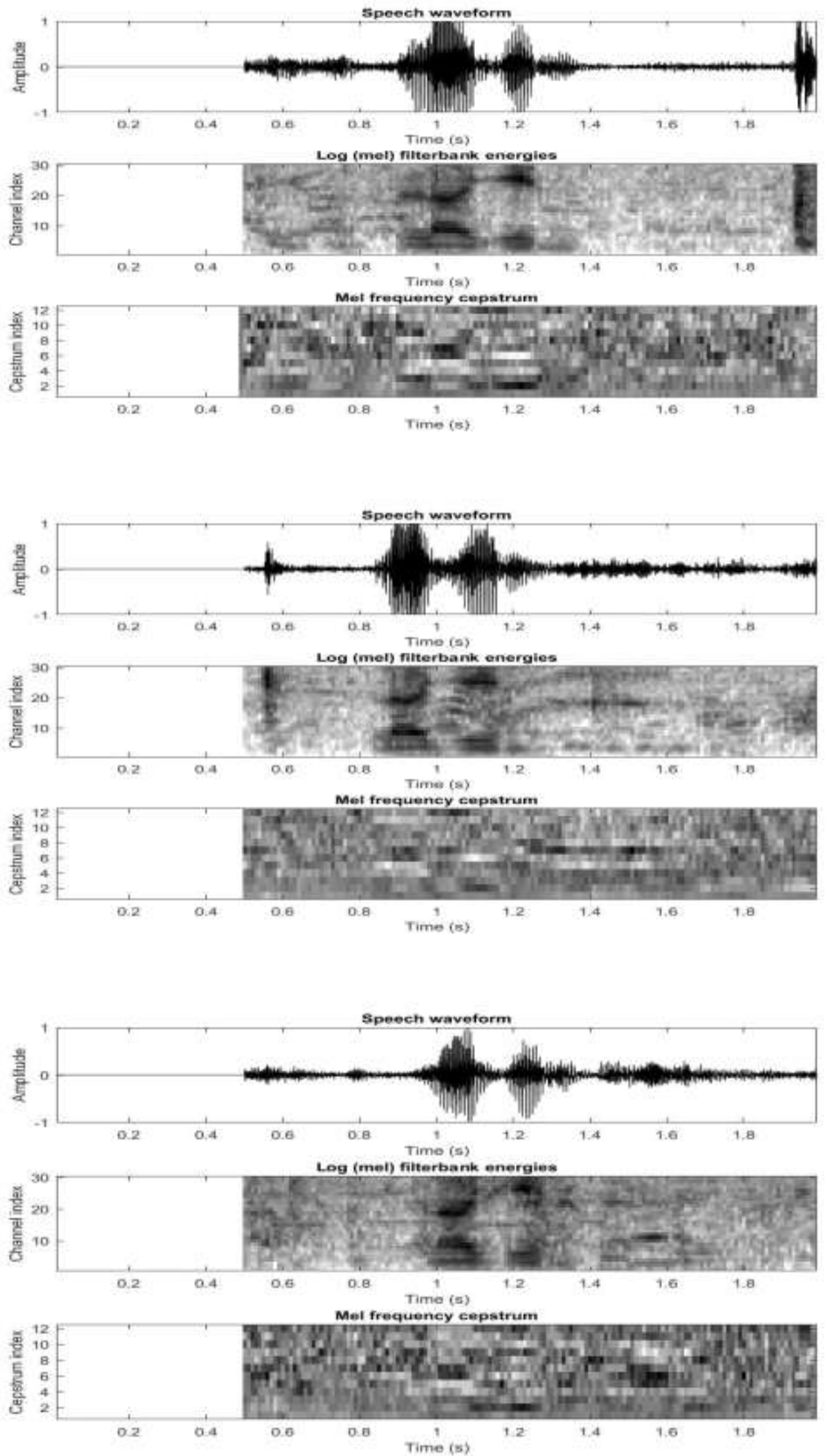

Gambar 2. Sampel ekstraksi suara 


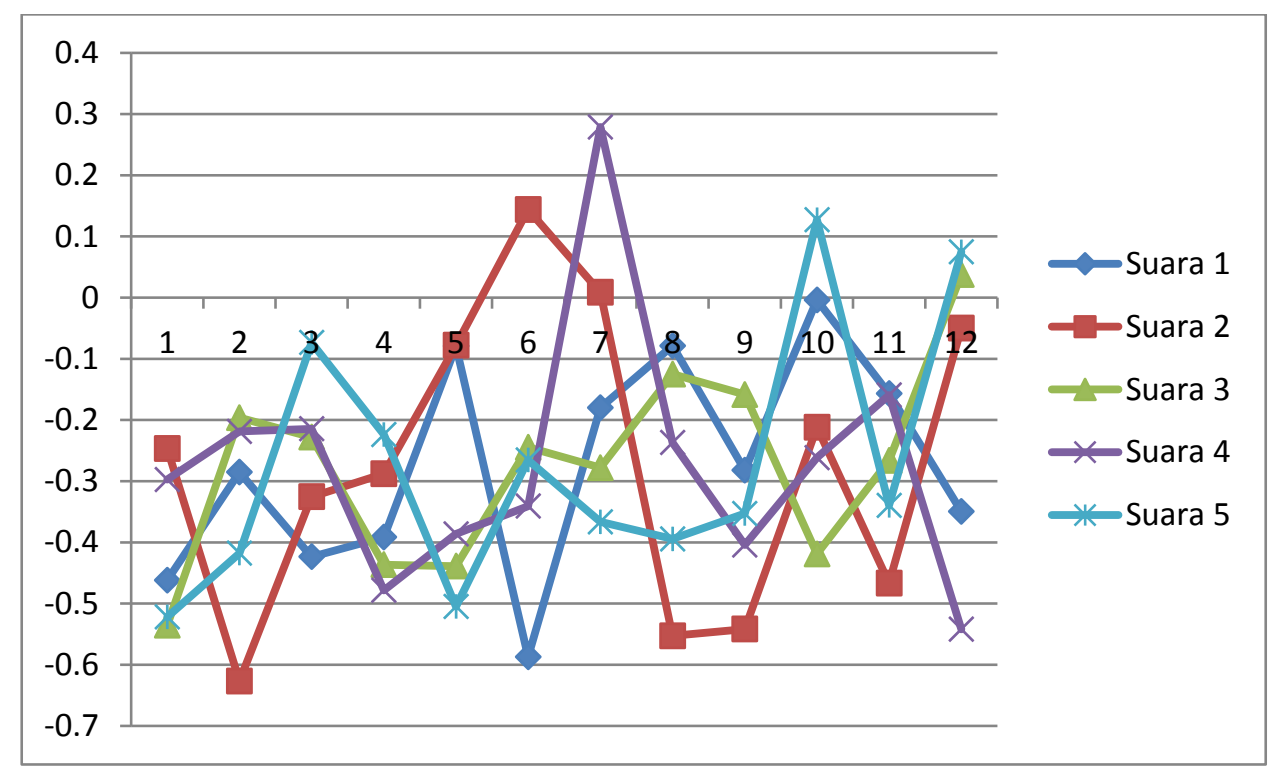

Gambar 3. Pola suara orang pertama

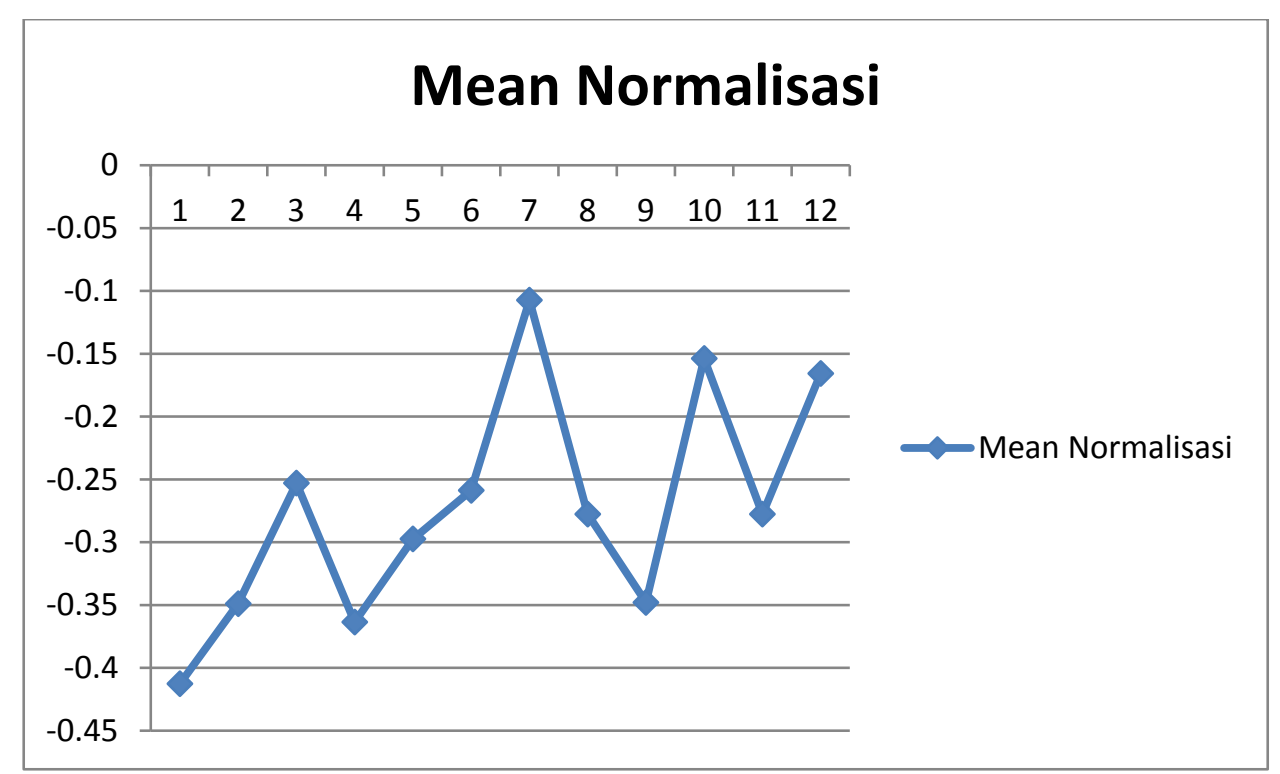

Gambar 4. Pola pola suara orang pertama yang telah dinormalisasi 


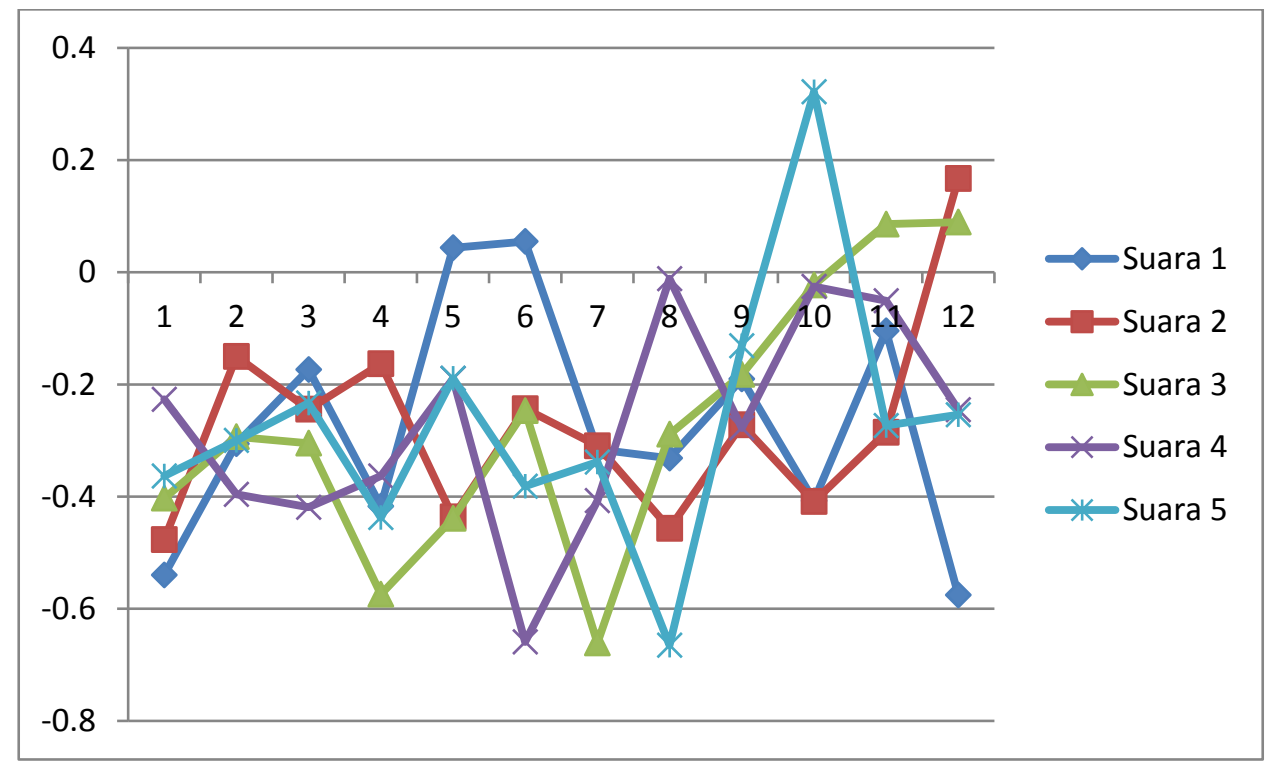

Gambar 5. Pola suara orang kedua

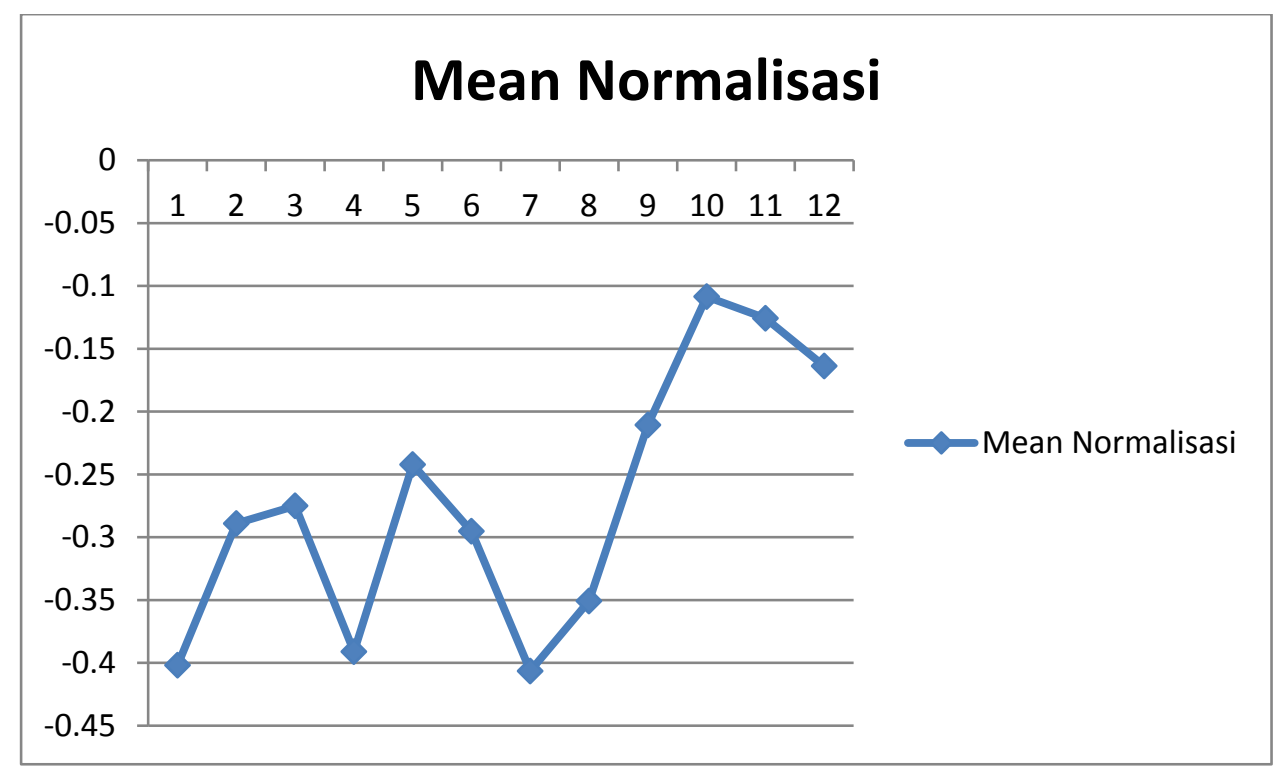

Gambar 6. Pola pola suara orang kedua yang telah dinormalisasi 


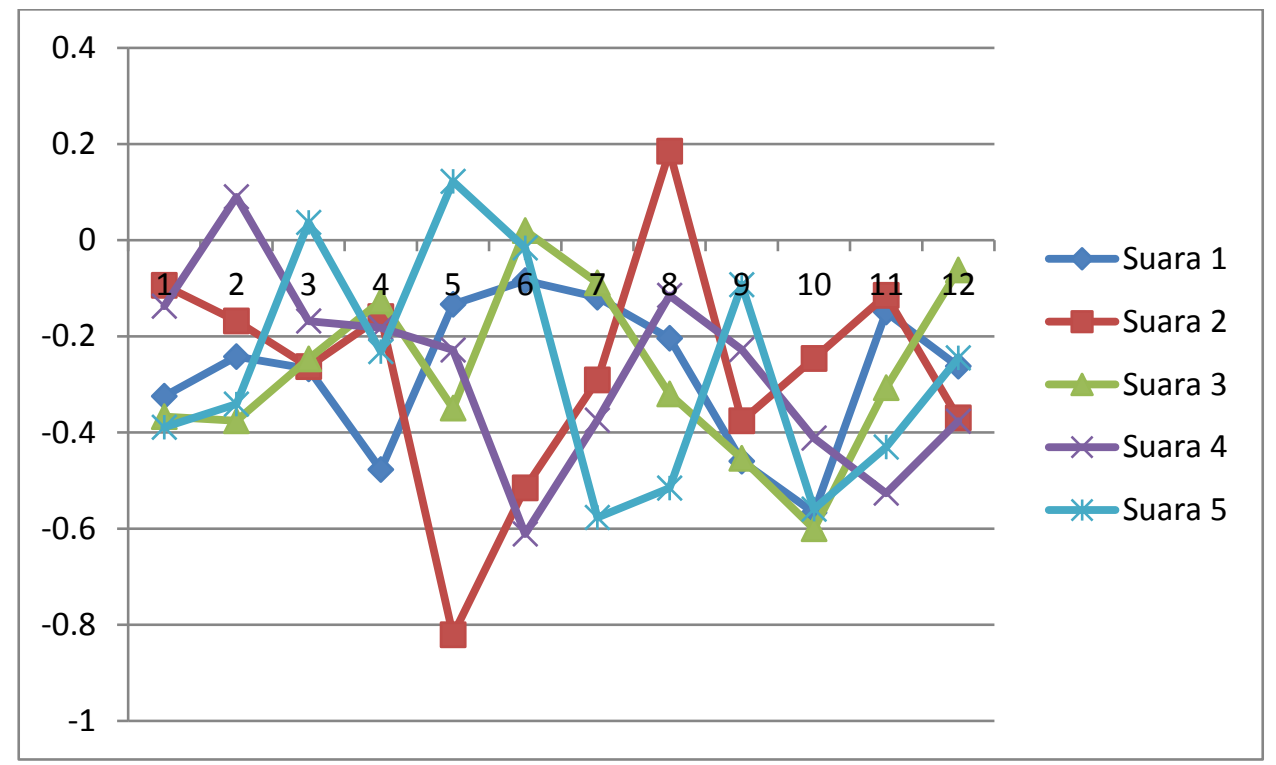

Gambar 7. Pola suara orang ketiga

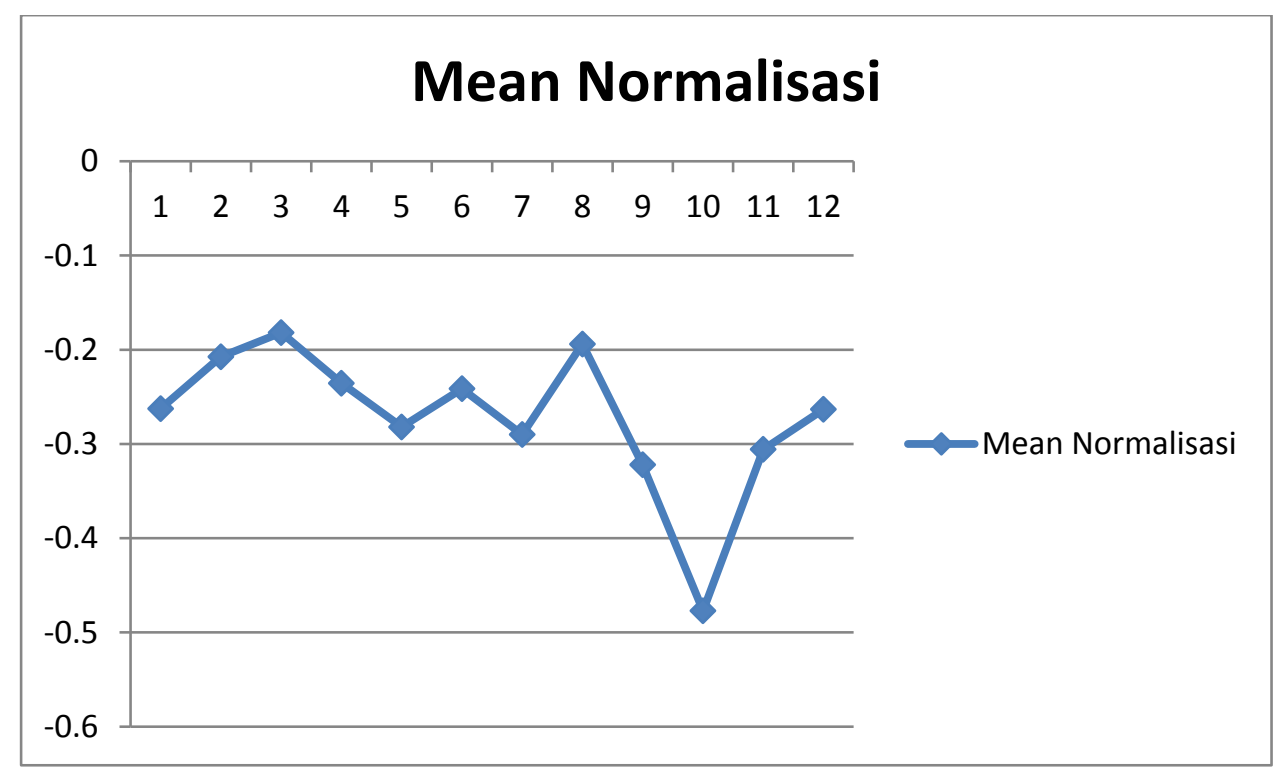

Gambar 8. Pola pola suara orang ketiga yang telah dinormalisasi 


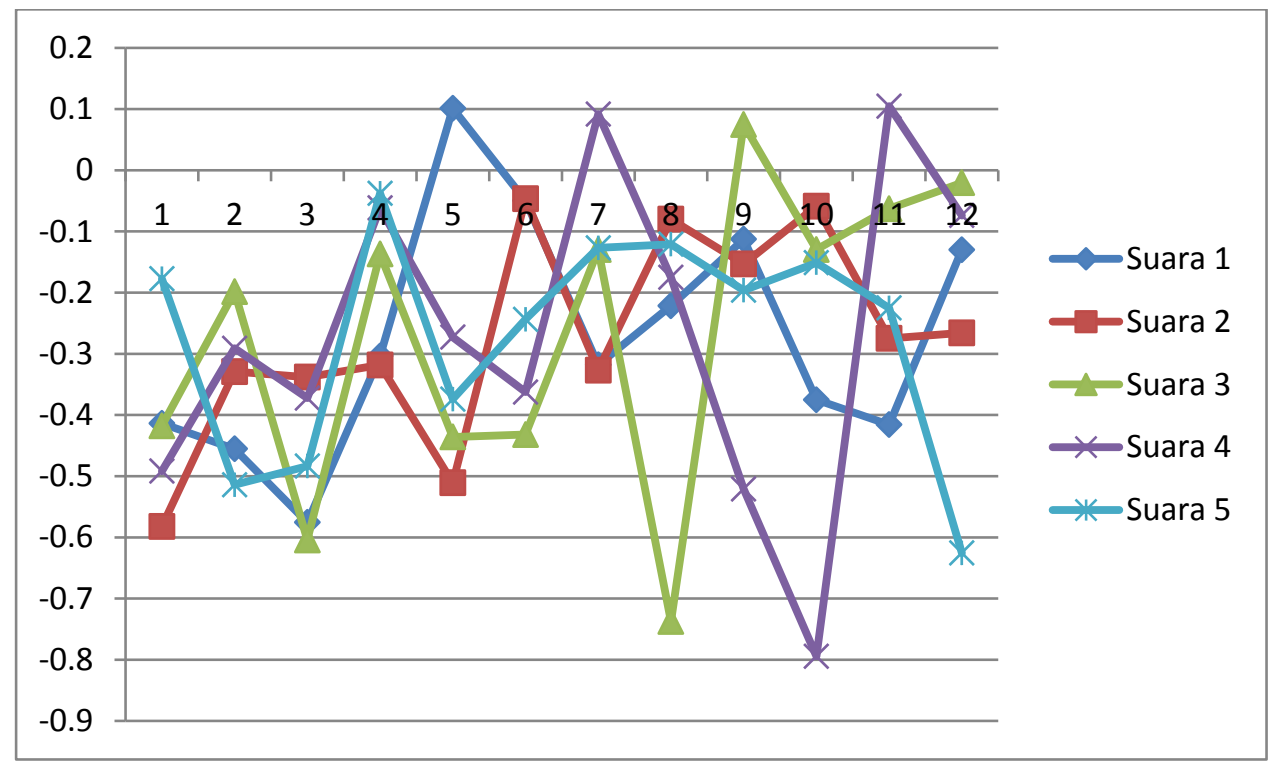

Gambar 9. Pola suara orang keempat

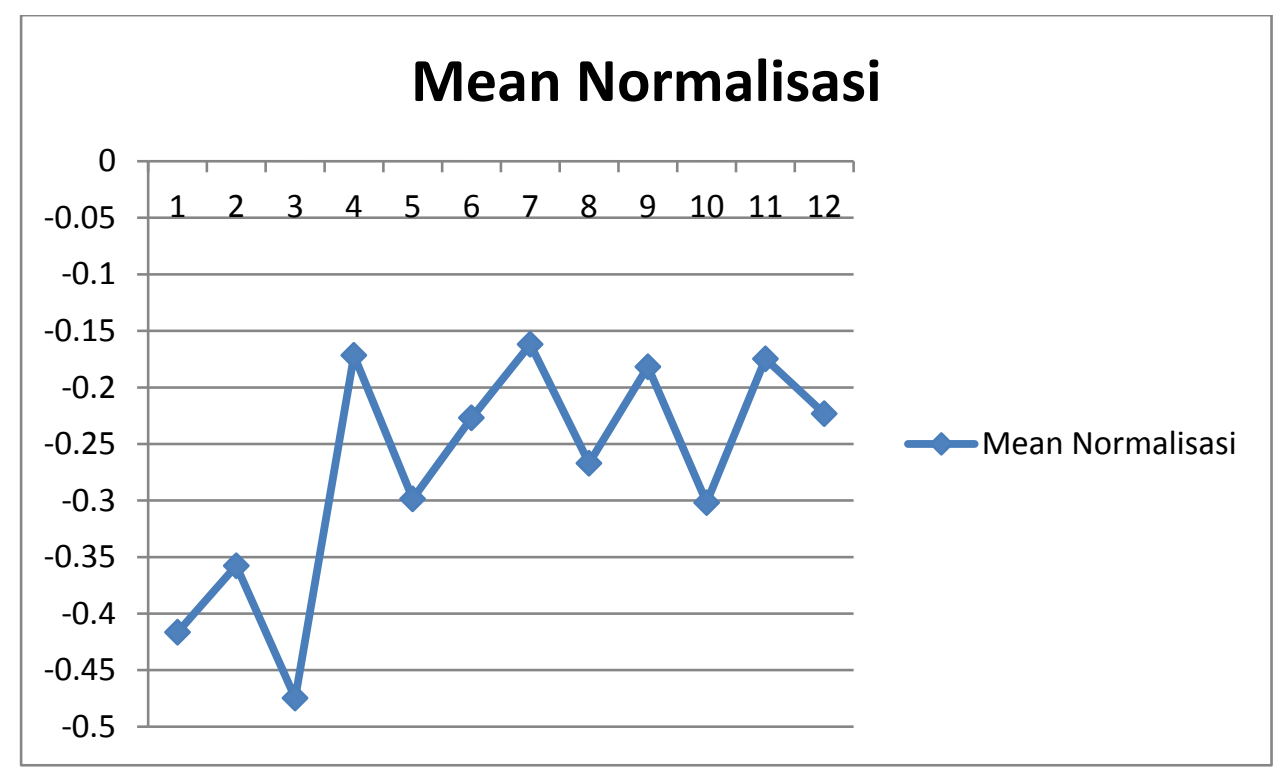

Gambar 10. Pola pola suara orang keempat yang telah dinormalisasi 


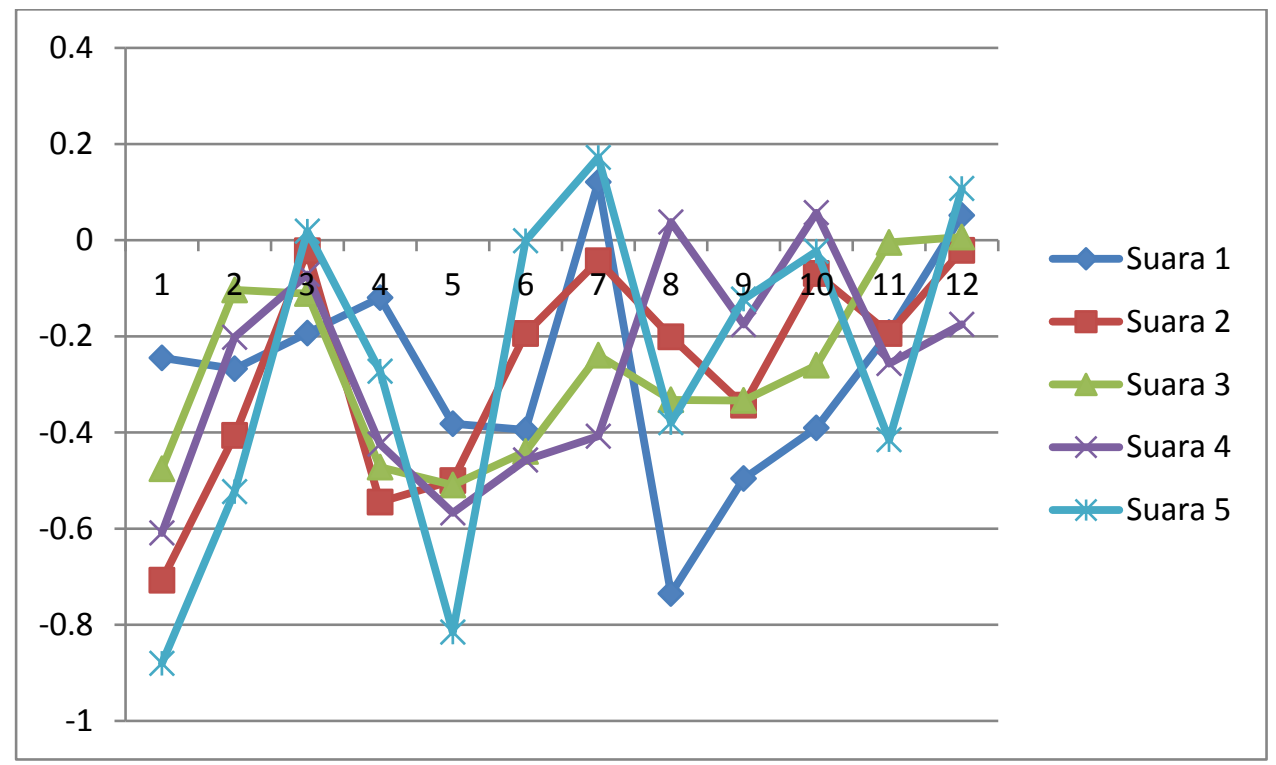

Gambar 11. Pola suara orang kelima

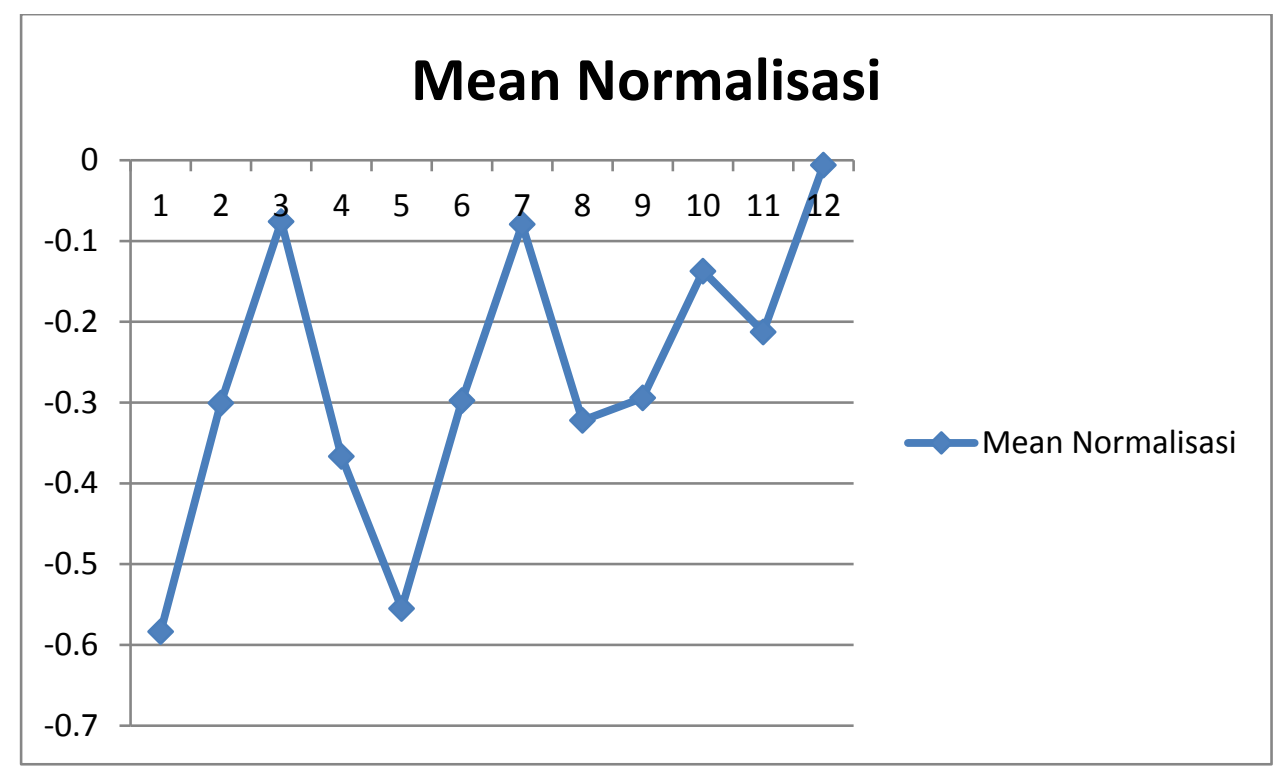

Gambar 12. Pola pola suara orang kelima yang telah dinormalisasi

Orang 1

\begin{tabular}{|l|c|c|c|c|c|c|}
\hline Ciri & N1 & N2 & N3 & N4 & N5 & $\begin{array}{c}\text { Mean } \\
\text { Normalisasi }\end{array}$ \\
\hline MFCC1 & 3,280 & 3,235 & 3,288 & 3,262 & 3,259 & 3,265 \\
\hline MFCC2 & $-0,462$ & $-0,247$ & $-0,536$ & $-0,297$ & $-0,522$ & $-0,413$ \\
\hline MFCC3 & $-0,285$ & $-0,627$ & $-0,196$ & $-0,219$ & $-0,418$ & $-0,349$ \\
\hline
\end{tabular}




\begin{tabular}{|l|c|c|c|c|c|c|} 
MFCC4 & $-0,424$ & $-0,325$ & $-0,228$ & $-0,215$ & $-0,074$ & $-0,253$ \\
\hline MFCC5 & $-0,392$ & $-0,288$ & $-0,436$ & $-0,478$ & $-0,224$ & $-0,364$ \\
\hline MFCC6 & $-0,079$ & $-0,078$ & $-0,439$ & $-0,386$ & $-0,505$ & $-0,297$ \\
\hline MFCC7 & $-0,587$ & 0,144 & $-0,245$ & $-0,341$ & $-0,266$ & $-0,259$ \\
\hline MFCC8 & $-0,180$ & 0,009 & $-0,278$ & 0,279 & $-0,366$ & $-0,107$ \\
\hline MFCC9 & $-0,079$ & $-0,553$ & $-0,125$ & $-0,237$ & $-0,395$ & $-0,278$ \\
\hline MFCC10 & $-0,282$ & $-0,542$ & $-0,158$ & $-0,404$ & $-0,353$ & $-0,348$ \\
\hline MFCC11 & $-0,004$ & $-0,212$ & $-0,419$ & $-0,262$ & 0,127 & $-0,154$ \\
\hline MFCC12 & $-0,157$ & $-0,467$ & $-0,266$ & $-0,159$ & $-0,340$ & $-0,278$ \\
\hline MFCC13 & $-0,349$ & $-0,050$ & 0,038 & $-0,542$ & 0,075 & $-0,166$ \\
\hline
\end{tabular}

Orang 2

\begin{tabular}{|l|c|c|c|c|c|c|}
\hline Ciri & N1 & N2 & N3 & N4 & N5 & $\begin{array}{c}\text { Mean } \\
\text { Normalisasi }\end{array}$ \\
\hline MFCC1 & 3,264 & 3,280 & 3,241 & 3,272 & 3,246 & 3,261 \\
\hline MFCC2 & $-0,540$ & $-0,477$ & $-0,403$ & $-0,227$ & $-0,363$ & $-0,402$ \\
\hline MFCC3 & $-0,306$ & $-0,150$ & $-0,293$ & $-0,396$ & $-0,300$ & $-0,289$ \\
\hline MFCC4 & $-0,174$ & $-0,244$ & $-0,305$ & $-0,419$ & $-0,233$ & $-0,275$ \\
\hline MFCC5 & $-0,417$ & $-0,163$ & $-0,574$ & $-0,363$ & $-0,437$ & $-0,391$ \\
\hline MFCC6 & 0,044 & $-0,436$ & $-0,439$ & $-0,190$ & $-0,189$ & $-0,242$ \\
\hline MFCC7 & 0,055 & $-0,243$ & $-0,247$ & $-0,659$ & $-0,382$ & $-0,295$ \\
\hline MFCC8 & $-0,316$ & $-0,310$ & $-0,661$ & $-0,407$ & $-0,338$ & $-0,406$ \\
\hline MFCC9 & $-0,332$ & $-0,457$ & $-0,289$ & $-0,012$ & $-0,665$ & $-0,351$ \\
\hline MFCC10 & $-0,190$ & $-0,272$ & $-0,182$ & $-0,278$ & $-0,131$ & $-0,211$ \\
\hline MFCC11 & $-0,408$ & $-0,409$ & $-0,023$ & $-0,025$ & 0,322 & $-0,109$ \\
\hline MFCC12 & $-0,105$ & $-0,286$ & 0,086 & $-0,051$ & $-0,273$ & $-0,126$ \\
\hline MFCC13 & $-0,576$ & 0,167 & 0,089 & $-0,245$ & $-0,254$ & $-0,164$ \\
\hline
\end{tabular}

Orang 3

\begin{tabular}{|l|c|c|c|c|c|c|}
\hline Ciri & N1 & N2 & N3 & N4 & N5 & $\begin{array}{c}\text { Mean } \\
\text { Normalisasi }\end{array}$ \\
\hline MFCC1 & 3,291 & 3,234 & 3,279 & 3,270 & 3,240 & 3,263 \\
\hline MFCC2 & $-0,325$ & $-0,094$ & $-0,367$ & $-0,137$ & $-0,389$ & $-0,262$ \\
\hline MFCC3 & $-0,242$ & $-0,168$ & $-0,376$ & 0,090 & $-0,341$ & $-0,207$ \\
\hline MFCC4 & $-0,268$ & $-0,263$ & $-0,247$ & $-0,168$ & 0,037 & $-0,182$ \\
\hline MFCC5 & $-0,477$ & $-0,159$ & $-0,126$ & $-0,183$ & $-0,232$ & $-0,236$ \\
\hline MFCC6 & $-0,133$ & $-0,821$ & $-0,350$ & $-0,228$ & 0,122 & $-0,282$ \\
\hline MFCC7 & $-0,084$ & $-0,516$ & 0,020 & $-0,611$ & $-0,016$ & $-0,241$ \\
\hline MFCC8 & $-0,119$ & $-0,291$ & $-0,089$ & $-0,374$ & $-0,577$ & $-0,290$ \\
\hline MFCC9 & $-0,204$ & 0,185 & $-0,320$ & $-0,115$ & $-0,516$ & $-0,194$ \\
\hline MFCC10 & $-0,460$ & $-0,376$ & $-0,454$ & $-0,228$ & $-0,093$ & $-0,322$ \\
\hline MFCC11 & $-0,567$ & $-0,246$ & $-0,601$ & $-0,412$ & $-0,560$ & $-0,477$ \\
\hline MFCC12 & $-0,150$ & $-0,115$ & $-0,307$ & $-0,526$ & $-0,431$ & $-0,306$ \\
\hline MFCC13 & $-0,262$ & $-0,370$ & $-0,062$ & $-0,377$ & $-0,245$ & $-0,263$ \\
\hline
\end{tabular}


Orang 4

\begin{tabular}{|l|c|c|c|c|c|c|}
\hline Ciri & N1 & N2 & N3 & N4 & N5 & $\begin{array}{c}\text { Mean } \\
\text { Normalisasi }\end{array}$ \\
\hline MFCC1 & 3,270 & 3,284 & 3,231 & 3,220 & 3,276 & 3,256 \\
\hline MFCC2 & $-0,414$ & $-0,582$ & $-0,418$ & $-0,492$ & $-0,177$ & $-0,417$ \\
\hline MFCC3 & $-0,455$ & $-0,329$ & $-0,199$ & $-0,291$ & $-0,514$ & $-0,358$ \\
\hline MFCC4 & $-0,576$ & $-0,338$ & $-0,604$ & $-0,372$ & $-0,484$ & $-0,475$ \\
\hline MFCC5 & $-0,304$ & $-0,318$ & $-0,137$ & $-0,062$ & $-0,038$ & $-0,172$ \\
\hline MFCC6 & 0,101 & $-0,511$ & $-0,436$ & $-0,273$ & $-0,374$ & $-0,298$ \\
\hline MFCC7 & $-0,050$ & $-0,047$ & $-0,432$ & $-0,363$ & $-0,244$ & $-0,227$ \\
\hline MFCC8 & $-0,318$ & $-0,327$ & $-0,130$ & 0,092 & $-0,127$ & $-0,162$ \\
\hline MFCC9 & $-0,221$ & $-0,080$ & $-0,738$ & $-0,175$ & $-0,121$ & $-0,267$ \\
\hline MFCC10 & $-0,113$ & $-0,153$ & 0,075 & $-0,521$ & $-0,196$ & $-0,182$ \\
\hline MFCC11 & $-0,375$ & $-0,059$ & $-0,130$ & $-0,794$ & $-0,151$ & $-0,302$ \\
\hline MFCC12 & $-0,416$ & $-0,275$ & $-0,063$ & 0,105 & $-0,225$ & $-0,175$ \\
\hline MFCC13 & $-0,130$ & $-0,266$ & $-0,020$ & $-0,074$ & $-0,626$ & $-0,223$ \\
\hline
\end{tabular}

Orang 5

\begin{tabular}{|l|c|c|c|c|c|c|}
\hline Ciri & N1 & N2 & N3 & N4 & N5 & $\begin{array}{c}\text { Mean } \\
\text { Normalisasi }\end{array}$ \\
\hline MFCC1 & 3,244 & 3,247 & 3,275 & 3,252 & 3,136 & 3,231 \\
\hline MFCC2 & $-0,245$ & $-0,708$ & $-0,476$ & $-0,609$ & $-0,880$ & $-0,584$ \\
\hline MFCC3 & $-0,268$ & $-0,406$ & $-0,104$ & $-0,202$ & $-0,523$ & $-0,301$ \\
\hline MFCC4 & $-0,193$ & $-0,022$ & $-0,111$ & $-0,071$ & 0,018 & $-0,076$ \\
\hline MFCC5 & $-0,120$ & $-0,545$ & $-0,472$ & $-0,424$ & $-0,273$ & $-0,367$ \\
\hline MFCC6 & $-0,382$ & $-0,500$ & $-0,509$ & $-0,567$ & $-0,816$ & $-0,555$ \\
\hline MFCC7 & $-0,395$ & $-0,194$ & $-0,440$ & $-0,457$ & $-0,002$ & $-0,298$ \\
\hline MFCC8 & 0,121 & $-0,043$ & $-0,239$ & $-0,408$ & 0,172 & $-0,079$ \\
\hline MFCC9 & $-0,735$ & $-0,201$ & $-0,332$ & 0,038 & $-0,380$ & $-0,322$ \\
\hline MFCC10 & $-0,496$ & $-0,343$ & $-0,333$ & $-0,175$ & $-0,123$ & $-0,294$ \\
\hline MFCC11 & $-0,390$ & $-0,069$ & $-0,260$ & 0,057 & $-0,023$ & $-0,137$ \\
\hline MFCC12 & $-0,192$ & $-0,194$ & $-0,005$ & $-0,257$ & $-0,415$ & $-0,213$ \\
\hline MFCC13 & 0,052 & $-0,021$ & 0,007 & $-0,175$ & 0,107 & $-0,006$ \\
\hline
\end{tabular}

Tabel 1. Tabel normalisasi 


\section{KESIMPULAN}

Hasil dari penelitan yang telah dilakukan dapat disimpulkan bawah ekstraksi fitur dengan menggunakan MFCC dapat dibedakan polanya untuk setiap suara dengan beberapa parameter yaitu $\mathrm{Tw}=25$; sebagai durasi masing-masing frame, $\mathrm{Ts}=10$; sebagai pembentukan frame, alpha $=0.97$; sebagai nilai koefesien preemphasis, $M=20$; sebagai nilai filterbank pada setiap channels, $C=12$; nilai cepstral coefficients, dari parameter tersebut dihasilkan fitur MFCC, hasil dari matriks MFCC tersebut kemudian dicari nilai rata-ratanya (mean) untuk cirinya. Hasil dari ciri mean tersebut menghasilkan pola-pola yang menjadikan ciri masing-masing suara. Setiap suara memiliki pola dan besaran spektrum yang berbeda-beda. Perbedaan spektrum dikarenakan pengaruh kualitas suara. Dengan identifikasi suara menggunakan MFCC ektstaksi ciri ini dapat digunakan untuk proses pengklasifikasian suara selanjutnya.

\section{DAFTAR RUJUKAN}

Abriyono, \& Harjoko, A. (2012). Pengenalan Ucapan Suku Kata Bahasa Lisan Menggunakan Ciri LPC, MFCC, dan JST. Indonesian Journal of Computing and Cybernetics Systems, 6(2), 23-34.

Aranda, J., Astari, W., \& Natasya, G. (2016). Penerapan Metode K-Means Cluster Analysis Pada Sistem Penerapan Metode K-Means Cluster Analysis Pada Sistem Pendukung Keputusan Pemilihan Konsentrasi Untuk, (January 2018).

Arifin, Z., Studi, P., Komputer, I., \& Mulawarman, F. U. (2010). Penerapan Metode Analytical Hierarchy Process ( AHP ) Untuk Menentukan Sisa Hasil Usaha Pada Koperasi Pegawai Negeri. Jurnal Informatika Mulawarman, 5 (Zainal Arifin), 1-12. https://doi.org/10.17605/JIM.V5I2.60

Nim, G. M., \& Uta, S. (2008). PENCOCOKAN POLA SUARA ( SPEECH RECOGNITION ) DENGAN ALGORITMA FFT DAN DIVIDE AND CONQUER.

Fadlisyah. Bustami.M.Ikhwanus. (2013) Pengolahan Suara.Graha Ilmu

Bhaskoro, S. B., Pelatihan, F. and Pengenalan, F. (2012) 'Aplikasi pengenalan gender menggunakan suara', 2012(Snati), pp. 15-16

Mega Tiara Nur Azizah (2017) 'APLIKASI PENGENAL PENGUCAP BERBASIS IDENTIFIKASI SUARA DENGAN EKSTRAKSI CIRI MEL-FREQUENCY CEPSTRUM COEFFICIENTS (MFCC) DAN KUANTISASI VEKTO', TRANSIENT, 6

Pengendali, S. and Elektronik, P. (2016) 'Aplikasi Pengenalan Suara Menggunakan Microsoft Sapi sebagai Pengendali Peralatan Elektronik', (January 2007).

Fadlil, A. et al. (2008) 'Pengembangan Sistem Basis Data Presensi Perkuliahan Dengan Kartu Mahasiswa Ber-Barcode', Telkomnika, 6(1), pp. 65-72.

Pengendali, S. and Elektronik, P. (2016) 'Aplikasi Pengenalan Suara Menggunakan Microsoft Sapi sebagai Pengendali Peralatan Elektronik', (January 2007).

Prodi, S. et al. (2017) 'PERANCANGAN SISTEM PENGENALAN SUARA DENGAN METODE LINEAR PREDICTIVE CODING SPEECH RECOGNITION SYSTEM DESIGN USING LINEAR PREDICTIVE CODING METHOD', 4(1), pp. 404-411.

Setiawan, A., Hidayatno, A. and Isnanto, R. R. (2011) 'Aplikasi Pengenalan Ucapan dengan Ekstraksi Mel-Frequency Cepstrum Coefficients ( MFCC ) Melalui Jaringan Syaraf Tiruan ( JST ) Learning Vector Quantization ( LVQ ) untuk Mengoperasikan Kursor Komputer', 13(3), pp. 82-86.

Sugiyono, P. D. (2011) Pendekatan Kuantitatif Kualitatif, dan R\&D. Bandung: ALFABETA.

Wijaya, R. F. and Utomo, R. B. (2018) 'KAMUS TERJEMAHAN BAHASA INDONESIA KE BAHASA INGGRIS DENGAN PENERAPAN SPEECH TO TEXT BERBASIS', 5(1), pp. 4447. 
Yudhana, A., Fadlil, A. and Prianto, Eko Teori, L. (2017) 'Kepegawaian Dan Kegiatan Berbasis Android', pp. 63-68. 